Journal of

Education and Practice

(JEP)

EXAMINATION OF THE ROLE OF PARENTS IN THE TEACHING LEARNING

PROCESS IN PUBLIC SCHOOLS IN LAIKIPIA WEST SUB-COUNTY, LAIKIPIA COUNTY, KENYA

Fr. Samuel Amugori Romata, Dr. Sr. Jacinta M. Adhiambo and Prof. Mary N. Getui

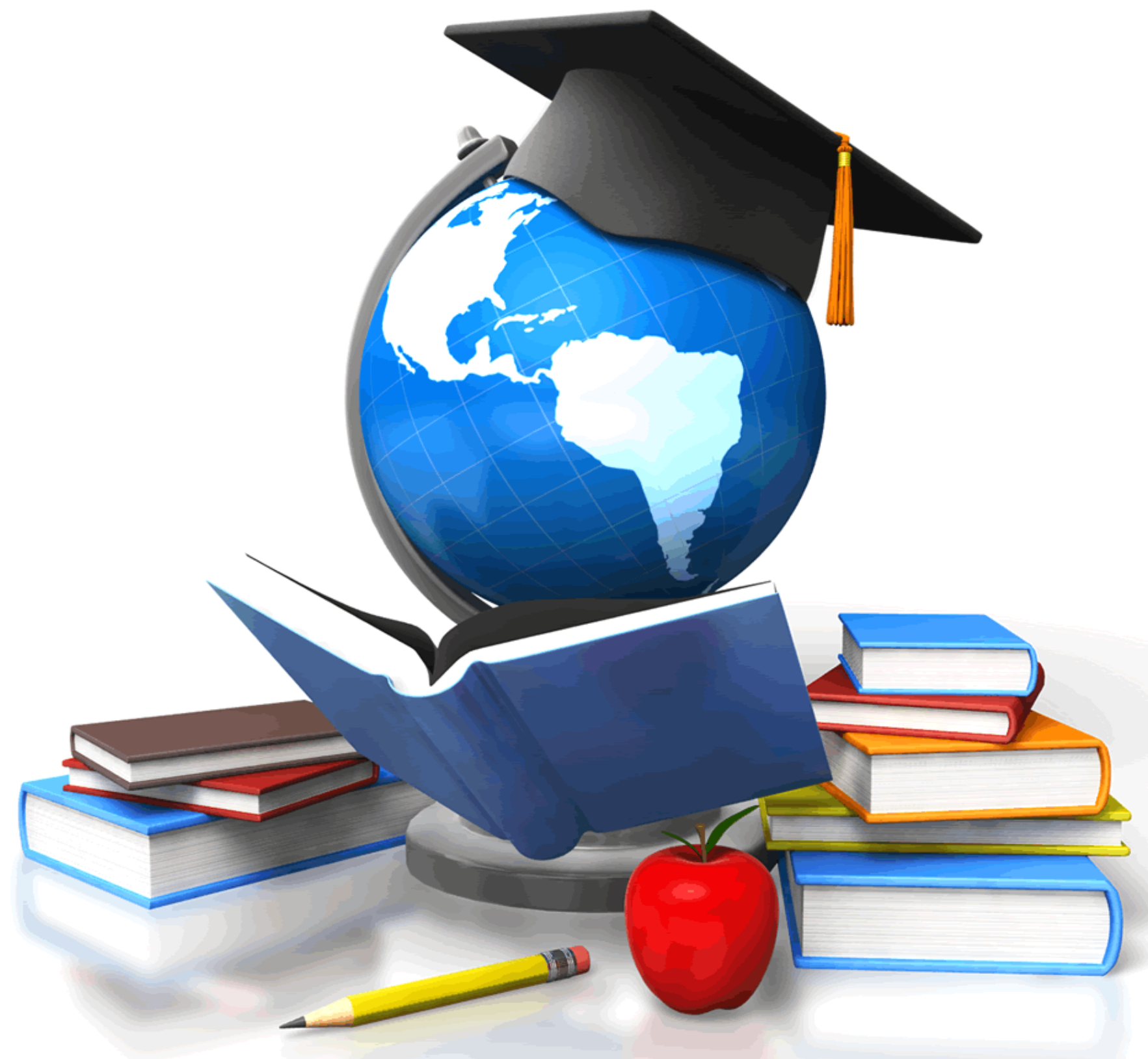

CARI 


\title{
EXAMINATION OF THE ROLE OF PARENTS IN THE TEACHING LEARNING PROCESS IN PUBLIC SCHOOLS IN LAIKIPIA WEST SUB-COUNTY, LAIKIPIA COUNTY, KENYA
}

\author{
Fr. Samuel Amugori Romata \\ Faculty of Education, Catholic University of Eastern Africa \\ Corresponding Author email: amugorisam@yahoo.com \\ Dr. Sr. Jacinta M. Adhiambo \\ Faculty of Education, Catholic University of Eastern Africa \\ Prof. Mary N. Getui \\ Faculty of Education, Catholic University of Eastern Africa
}

\begin{abstract}
Purpose: The study aimed at finding out whether parents play a role in the teaching learning process of pupils in public schools in public primary schools in Laikipia West sub-county.

Methodology: A mixed method research design was used where cross sectional descriptive survey was used on quantitative data and phenomenology was used to complement components of qualitative data. Population of 13 public Primary schools was sampled from the total 65 public Primary Schools in the Sub-County. Out of 2,236, pupils' in class 6, 7 and 8,3 girls and 3 boys were selected per class through stratification and simple random method. Parents/ guardians for the selected pupils were purposively selected regardless of their age, level of education and gender. All class teachers from the sampled schools were targeted and purposively selected. The data was collected using questionnaires, interview guide, document analysis guide and focus discussion guide. Statistical Package for Social Sciences (SPSS) version 17 was used to analyze quantitative data.
\end{abstract}

Results: The results from the study showed that there is prevalence of parental roles on the pupil's learning process in Laikipia West Sub- County mainly through attending school functions, assisting with homework, communicating with teachers and their children and provision of learning resources.

Unique Contribution to Theory, Practice and Policy: The recommendation was that those parents who were not actively involved on pupil's academic related matters be sensitized on their roles of promoting child education. The County as well as national governments should support parents by establishing structures and policies that boost the standard of education in the area. According to this study such policies includes; establishing efficient and effective guidance and counseling programs in school, taking legal action on parents who keep their children at home, providing full sponsorship to needy parents and establishing boarding schools among the pastoralists communities.

Key Words: Parental Involvement, Academic Activities, Teaching Learning Process, and Public Schools 
Journal of Education and Practice

ISSN 2520-467X (Online)

Vol.5, Issue No.3, pp 35 - 53, 2021

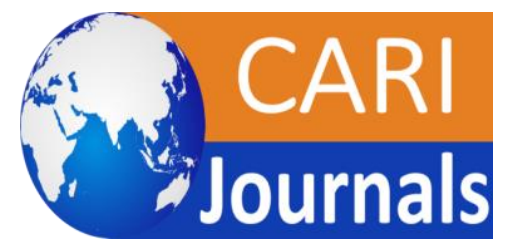

WWW.carijournals.org

\section{INTRODUCTION}

Currently, education is the prime mover of any socio-economic and political development of a nation. Therefore, individuals, communities and states spend many human and material resources in order to achieve educational results. However, for the realization of social and individual benefits of education, stakeholders need to set up clear policies that would lead to the realization of education agenda, which includes provision of quality education to all irrespective of geographical location, political affiliation and ethnic background. As key players in educational agenda, parents ought to maximize their contribution of time and resources in order to influence pupil's participation in academic activities. A study conducted by Cohen-Vogel and Smrekar (2001) on the voice of parents; rethinking the intersection of family and School in California found out that parents describe their roles in schools as task oriented. When parents are actively engaged in teaching and learning process of their children, when they provide the necessary resources that support education of their children and when they make follow up of pupil's academic progress, the chances of pupils' participation in academic activities are high. This means that pupils improve in asking questions in class, attending school regularly, joining study groups and finishing assignments in time. A positive interaction between parental influence and pupils' participation in academic activities result to improved pupils retention rate, high completion and consistent transition rate in schools.

Consequently, parents in adherence to their parental roles and obligations in the education of their children make numerous sacrifices. Some parents are found to use their time, resources and skills to ensure that their children progress academically. In support of this, Kiveu and Mayio (2009) have pointed out that a parent in Kenya shoulders $60 \%$ of the total expenditure of secondary education. According to Kiveu and Mayio, the reason of allocating huge amount of funds is to ensure that parents are more involved in the education of their children. In their published study on planning and economic of education, Chiuri and Kiumi (2005) pointed out that, in order to enjoy the benefits accrued from investment in education, parents have to incur costs. A similar idea was echoed by United States Agency for International Development (USAID) (2010) report that affirmed that many countries, parents spend a significant portion of their income on educating children, a burden that is often a challenge to poor families.

In reference to their natural obligation, parents ought to be actively involved in education of their children. This notwithstanding, some of the Head teachers during the Sub-County Head teachers meeting held in March 2011, revealed that there is an increase on pupils demotivation particularly in academic activities such as asking questions in class, finishing assignment on time, attending school regularly and joining study groups. According to the report, such pupils end up dropping from school to seek for employment and early marriages. The irony is that the same report reveals that a significant number of the pupils in the same schools are self-motivated and thus requires less supervision.

\section{Statement of the Problem}

There has been a marked increase of pupils de-motivation in academic activities in public primary schools in Laikipia West Sub-County. Head teacher's forum (2011) revealed that some pupils do not attend school regularly, they do not finish their homework on time nor do they ask questions in class. According to head teachers, such pupils eventually end up 
Journal of Education and Practice

ISSN 2520-467X (Online)

Vol.5, Issue No.3, pp $35-53,2021$

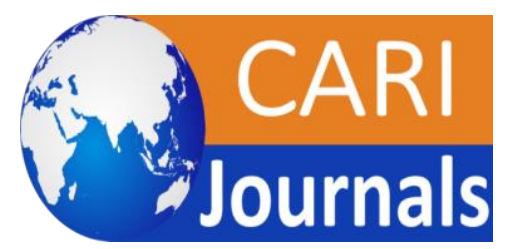

www.carijournals.org

dropping out of school for either child labor; early marriages and even joining outlawed groups. Head teachers during the forum revealed that at least six girls from each school dropout every year due to early marriage, at least four boys dropout in third term to join moranism, and at least five girls and six boys' drop out to look for employment. However, despite the government initiative of financing education programs, improving school infrastructure, introducing feeding program, staffing and establishing guidance and counseling programs (Odindo 2010), the challenge of pupils de-motivation on academic activities has been on the increase. Although the reviewed studies indicates that parents have the ability and capacity to influence their children in academic activities, perhaps carrying out this study among the parents of Laikipia West Sub-County could give different the results because of differences in social-economic, cultural beliefs and practices and geographical factors. Most of the studies reviewed were carried out in high schools where students are believed to be mature and self-motivated as compared to their counterparts in primary schools. Thus conducting the same study in primary schools might provide varied results. Most of the reviewed literatures were carried out in an urban set up where issues of insecurity, distance from school and cultural influence may not be as acute as compared to rural set part. Therefore, conducting this study in Laikipia West Sub-County rural public primary schools may give varying results.

\section{Research Questions}

i. How do parents in Laikipia West Sub-County assist their children to do school assignment?

ii. How do parents in Laikipia West Sub-County attend school functions

iii. How effective is the communication between parents, class teachers and pupils in Laikipia West Sub-County?

\section{Theoretical Literature Review}

\section{Social Learning Theory}

Social Learning Theory proposed by Albert Bandura in 1977 guided this study. The theory holds that people can learn new information and behavior by watching others. This means that human learning occurs in a social environment through observing others, whereby they acquire knowledge of rules, skills, strategies, beliefs and attitudes. The theory further teaches that cognitive development alone cannot explain changes in children behavior unless social and economic considerations are considered. Social Learning Theory highlights the idea that much of human learning occurs in a social environment where both teachers/administration, school structure and resources, learning disabilities, safety and pupils willingness to learn, age of the pupil, interest, attention, mental and physical health are all in course. According to this theory, children build an effective academic background when they observe how their parents and other siblings, environment and teachers interact with them. According to Bandura, environmental reinforcement is not the only factor to influence learning and behavior. For him intrinsic reinforcement such as pride; satisfaction and sense of accomplishment also influence learning. He viewed direct reinforcement as a direct influence in the learners' learning process and considered indirect reinforcement as the consequences of behaviors expressed by what the child may view as a model. The learners may consider teachers, parents and environment as a model to be imitated regardless of the consequences. However, not all parents and teachers are role models; therefore, pupils may be intrinsically 
Journal of Education and Practice

ISSN 2520-467X (Online)

Vol.5, Issue No.3, pp $35-53,2021$

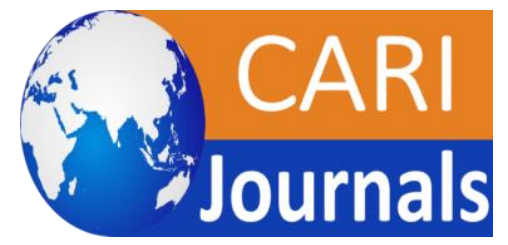

www.carijournals.org

motivated in order to undertake academic activities with minimal support from parents and teachers.

\section{Social interaction theory}

Social Interaction Theory attributed to Vygotsky (1978) stresses that symbolic meaning develop and depend upon the process of interaction. According to Vygosky interactionists believes that language is a product of children social interactions with important information. The theory further states that the environment plays a vital role in language and cognitive development. According to this theory, there exists a meaningful interaction between adults and children, which can influence language and cognitive development of the children. Schafer (2010) interpreted interactional theory as ongoing relationships created by particular words exchanged in a specific interaction. The significant starting point is that people can create their relationships with others every time they interact. Referring to Bateson (1980) teaching on how non-contact and competitive schooling blend art and epistemology, Stephen and Karen (2009) observed that communication is a vehicle of discovering important interaction patterns in human behavior. Interaction between parents and pupils or between pupils and teachers alone without material support and follow up strategies might not bear fruits in the pupils' learning process.

\section{Conceptual Framework}

PARENTAI INTIUENTEE

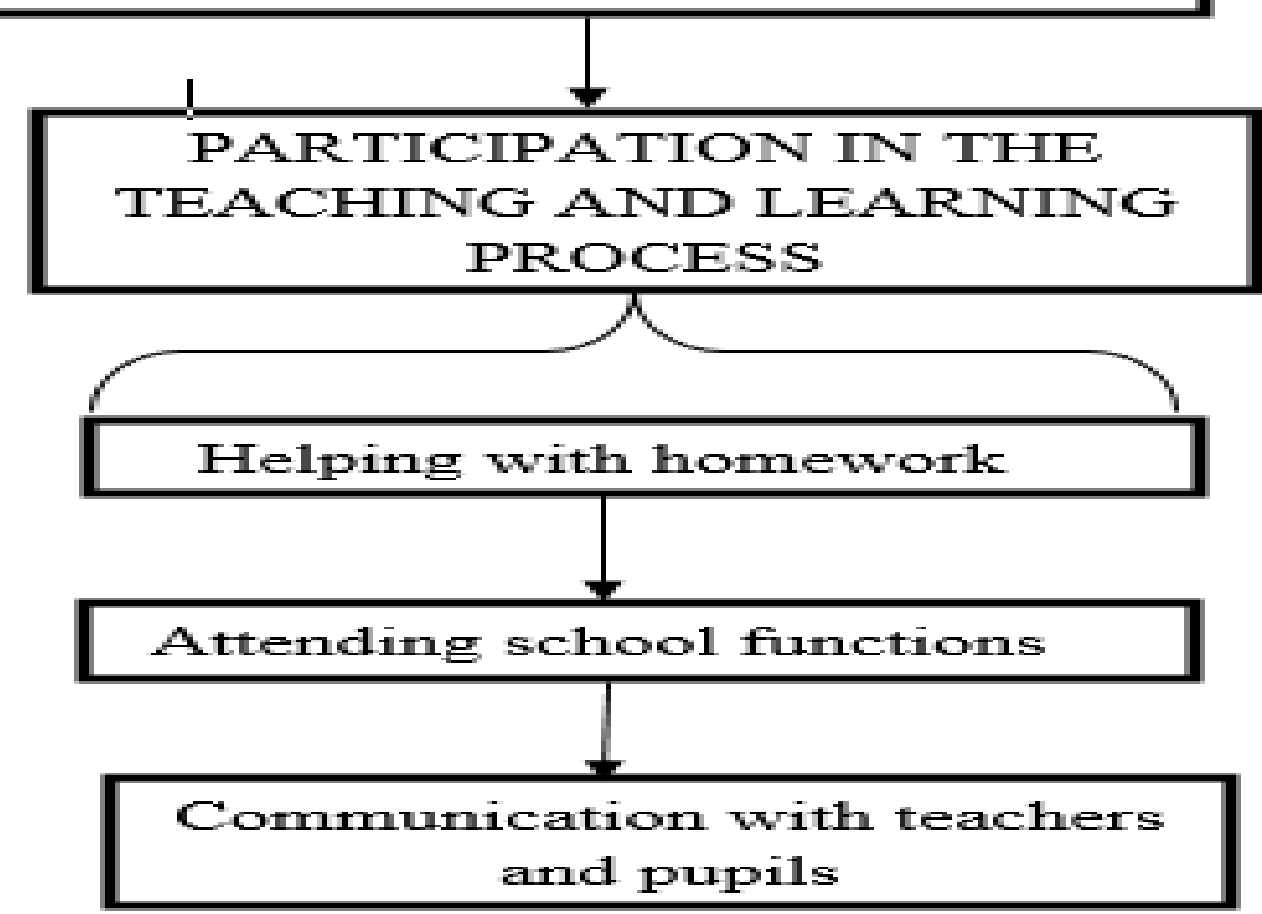

Figure 1: Conceptual Framework

The role of Parents in the teaching learning process Assisting Pupils with Homework 
Journal of Education and Practice

ISSN 2520-467X (Online)

Vol.5, Issue No.3, pp $35-53,2021$

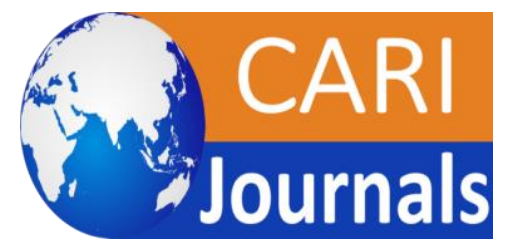

www.carijournals.org

Homework is the foundation upon which academic achievements is anchored; therefore, parents, teachers and other family members play a great role in stifling or promoting it. The study conducted by Hein and Wimer (2007) on improving homework completion and motivation, indicate that homework is important because it is an intersection between home and school. It acts as a window through which you can observe your children's education and express positive attitudes towards your children and their education. They identified six constructive purposes for homework in the context of child educational experience. This constructive purpose means that homework enables the learner to improve in practice and participation in the learning task and it further improves their academic achievement towards generation of knowledge as well as mastery of the basic academic skills such as reading, writing and spelling. The pupil's ability to gather and organize necessary materials to complete the assignment strengthens their sense of responsibility and equally learns time management skills. School assignment also plays an administrative role for it offers schools an opportunity to inform parents about class activities and policies and helping schools achieve their overall missions of improving pupil's academic achievements. As the bridge that joins school and parents, homework, from the school perspective is an opportunity to monitor individual pupil's academic progress. Parents on the other hand are enabled to gain an understanding and appreciation of what takes place at school. When parents appreciate the kind of homework administered to their children, their attitude towards education is positively influenced.

Parents unlike other education stakeholders have a major responsibility of reinforcing their children behavior towards academic activities both at home and school. In their review on the importance of families and home environment, Bonci (2008) and Cole (2011) highlights that parents who advocate reading as a valuable and worthy activity, have children who are motivated to read and accomplish assignments in time. Tshabalala (2008) study on parental influence on pupils' participation in academic activities emphasized the role of parent in child education. Her study on empowerment in the primary school, North West University Michigan asserts that when parents are involved, learners have high graduation rates, better school attendance, increased motivation, better self-esteem and decreased use of drugs and alcohol. Although the study was conducted in primary schools, Tshabalala did not specify the category of schools involved. This study addressed classes 6,7 and 8 pupils public primary school in Laikipia West Sub-County.

According to Farrow et al (2000), the main purpose of homework is to reinforce and promote learning and most importantly to help learners acquire quality education. Although several factor may influence pupil from doing homework, Case (2008) in his study on why student do not do homework, observe that pupils may fail to do homework because they consider it as a boring activity that strain the mind. Such pupils according to Case do not pay attention to instructions given nor do they listen to teachers during the teaching process. Consequently, this may lead to misunderstanding of concept and impairs pupils listening skills and eventually difficulty in accomplishing homework. The role of parents in this case is to encourage their children to pay attention during class sessions as a way of empowering children concentration span. Secondly, Case further found that pupils who are not intellectually gifted might view homework as a cumbersome activity and thus end up forgetting or lacking time to designate for homework. Farrow et al (2000) in their study on homework and its contribution to learning by the peer group and environment observed that 
Journal of Education and Practice

ISSN 2520-467X (Online)

Vol.5, Issue No.3, pp 35 - 53, 2021

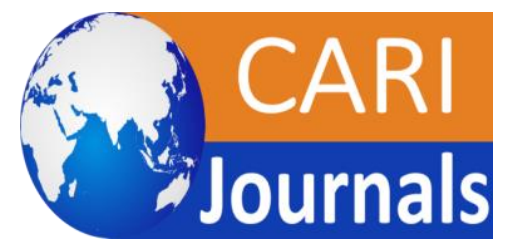

www.carijournals.org

there is a relationship between time spent on homework and pupils attitude towards school. Meaning that, pupils with negative attitude towards school spend little or no time at all doing homework. Such pupils believe in the importance of homework than those who dislike school (Farrow 2000). Case (2008) pointed that pupils may further fail to do homework due to factors such as expression of rebellion, not prioritizing homework, discouragement from parents and peers that there is no way in which they can improve their performance and lack of space and time to do homework. Some of the reasons need parent and teachers intervention, while others require pupil's initiative. A study conducted by Hallam (2004) on student, perspective on homework reveals that there is an increase in time spent on homework from primary instruction. However, factors such as motivation, mood, well-being family circumstance, the weather and quality and quantity of home assigned affect pupil's attitude towards doing their homework. According to Hallan, parents should intervene by providing necessary resources that would support and encourage pupils to develop positive attitude towards education. In considering these factors, this study identified parental influence has having a great role in influencing pupil's participation in completing homework.

On gender difference and homework, Warrington et al (2000) study on what works to improve achievement for boys and girls reveal that girls are keener with regard to homework and produce work that is neat, well planned and showed evidence of effort. In contrary boys appeared to dislike homework and spent least amount of time on it. According to Warrington and his companions, girls seem to be well motivated in homework than boys and since this study is concerned with pupil in general, it is wise to carry a different study on gender difference and homework. A study conducted by De Jong et al, (2000) on effects of homework, revealed that students study approach is related to achievement that is in agreement with Warrington et al (2000) study on what works to improve achievement for boys and girls. The study reveals that the time that pupils spent in a wide range of learning opportunities have a positive relationship with pupil's positive attitude towards education and achievement. Parental involvement in school-based activities is of paramount importance in the learning process of the child. Menahem, McGrath and Rich (2003) supported this idea. In their study carried out in North West University Michigan, Menahem et al had made the premise that, there is no relationship between parents helping children in homework and their economic status. This premise purports that parents are ready to assist pupils in the elementary or junior and even those who have finished high school with homework. This assistance is not pegged on parent's economic status or social position. Therefore, it is important that parents help their children with homework, as children develop wholesome habits and attitudes towards learning.

Parents themselves also learn more about their children education and thus communicate positive behavior, values and character traits at home as well as in school. The two studies were conducted in different geographical environment and among parents who might be better placed to meet pupil's educational requirements. This study was conducted in a multiethnic environment where cultural, socio-economic and attitude towards education may impact on parental influence and consequently affect pupils' participation in academic activities.

Supervising pupils in homework according to Epstein (2001) is a way of encouraging them to learn and a moment for parents to be involved in the learning process of their children. If 
Journal of Education and Practice

ISSN 2520-467X (Online)

Vol.5, Issue No.3, pp $35-53,2021$

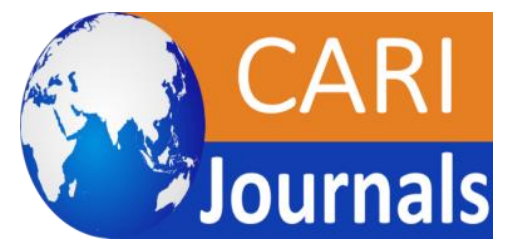

www.carijournals.org

pupils come to know that their parents and other members of the society are concerned about their academic progress, they actively participate without reservation. Parents could therefore encourage pupils to do their homework by removing distracters like television, set good example by reading and writing for those parents who are literate and engage children in activities that promote learning for example library visits, trips to geographical and historical sites and educational games. In reference to parental roles illustrated in the United State Department of Education(USDE) (2003) report on how parents can help children in homework, parents' involvement in pupils' homework can either create a positive or negative impact on the value of homework. On one-hand, parent's involvement can speed up a child learning process. When parents themselves value education, they establish a tradition of frequent communication with children and teachers. However, the report further explains that parents can sometimes interfere with learning if their teaching techniques differ from those used in school, if they get involved in completing tasks that the child is capable of completing alone, by so doing they dwarf the child's mental capacity and level of creativity. To avoid conflicting with school schedule on assignments, parents ought to support their children to accomplish homework by directly assisting them to do assignment, providing necessary materials and providing them with time and space for study.

The report reveals that, when parents positively assist their children with homework, effective communication between them and school improves because parents would understand and address the challenges cited by the teachers, while teachers would freely inform the parents on their children academic progress. This would give school administrators and teachers' opportunity to clarify what parents expect from students, parents on their side will get firsthand information about their children academic progress in school. Joan, Walker, Kathleen, Hoover-Dempsey, Darlene, Whetsel and Green (2004) observed that homework is a powerful tool which when used effectively can create impact on pupils' academic achievements. Therefore, according to Joan et al, assisting pupils in homework can allow parents and other adults know what the child is learning. This encourages children and parents to develop a habit of discussing what takes place in school, a scenario that gives teachers an opportunity to hear from parents how pupils respond to academic activities while at home. Joan et al further observed that assisting pupils in their homework could also enable parents to establish physical and psychological support that reinforce pupil's performance of homework. Because of economic constraints experienced in most families, some parents engage in multiple responsibilities to meet their basic needs. This reduces contact hours with their children, which could consequently lead to minimal or lack of supervision from the parents. These studies were conducted within an environment where parents are believed to be literate and committed to their pupil's academic performance. Such parents can easily seek audience with teachers on issues affecting pupil's academic activities. However, different results could be expected if a similar study is conducted in an area where some parents are illiterate, ignorant and are not committed to their parental roles on child education.

Parents should be involved in child education at both school and home. At home, Hoover, walker, Battiato, Reed and Dejong (2001) pointed that parents can specify regular time for homework, articulate and enforce expectations, and standardize and structure homework within the family timetable. This can enable them to monitor, supervise and attend to pupils needs related to school assignments. Most of the sampled schools are located in a rural set up where pupils after school assist their parents or guardians in household responsibilities; the 
Journal of Education and Practice

ISSN 2520-467X (Online)

Vol.5, Issue No.3, pp 35 - 53, 2021

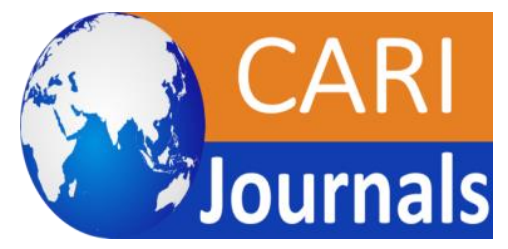

www.carijournals.org

researcher feels that parents in the area of study due to environmental conditions may find it difficult to allocate time and provide a friendly space for pupils to complete their school assignment in time. In order to assist pupils with homework, Menahem, McGrath and Rich (2003) encouraged that parents need to reinforce and reward pupil's efforts by ensuring that they have effectively corrected and completed their homework. They should also offer emotional and moral support when needed. Assisting children in homework can enable parents and students to develop a healthy interactive relationship, which encourages pupils to appreciate learning. Interactive process incorporates tutoring, guiding and mentoring pupils in academic activities. Irrespective of their education level and economic status, parents have the capacity and power to guide and mentor their children towards learning. Although parents have the power to guide and mentor their children, there is need to find out whether parents in the area of study could mentor and guide pupils to improve their performance on academic activities.

Pupils who receive parental support through frequent communication accomplish their assignments in time as indicated by Menahem, McGrath and Rich (2003). According to them, parents have a greater responsibility of assisting their children in homework, whether they are rich or poor, whether they have finished high school or not. When pupils are assisted in homework, they develop study skills that will be of value even after they leave school. These skills enable them to view education not as a burden or punishment but as a beneficial activity to them as individuals and the society. When pupils develop a positive attitude towards homework, they tend to believe that learning is a noble practice necessary for human development, intellectual formation and process that fosters positive character traits such as independence and responsibility. A study conducted by Joan et al (2004) on parents' involvement in homework reveals that homework gives pupils an opportunity to take any assignment as purposeful in their academic growth through the assistance of parents and other members of the school community. The study conducted by Menahem et al (2003) categorized homework into; practice homework that aims at reinforcing learning and helps pupils to master specific skills; preparation homework introduces materials that might be presented in the future lessons. Extension homework aims at asking pupils to apply skills already learnt to new situations and finally, integration homework requires the pupils to apply many different skills to a single task for example carrying out science project or creative writing. Therefore, homework can play an important role in determining pupils' participation in academic activities.

Parental support and encouragement enables pupils to accomplish assignments in time, encourage pupils to develop a positive attitude towards education. Different parents may support and encourage their children differently depending on their cultural, social economic and religious backgrounds. Therefore, conducting this study in a different environment and within a multi-racial community may possibly bring out varied results.

A study conducted by Kiprop (2005) on the influence of parent's background on students' attitude towards education in secondary schools, in Mbogo-ini division, Nakuru District, Kenya, indicates that parents play a vital role in the formation of their children. Kiprop used survey design and targeted head teachers, teachers, parents and students. He used Questionnaires, interview and focused group discussion guide as instruments to collect data. His findings indicated that students who receive motivation from home have higher aspirations and positive attitude towards excelling in academic performance. In order to 
Journal of Education and Practice

ISSN 2520-467X (Online)

Vol.5, Issue No.3, pp $35-53,2021$

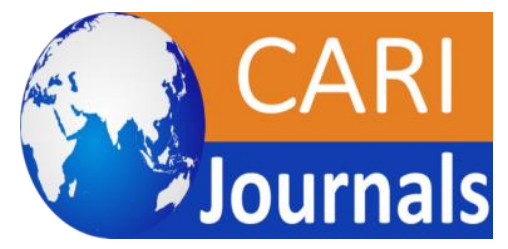

www.carijournals.org

involve the parent, Kiprop encouraged school administrators to sensitize parents on their roles of motivating students socially, financially and physiologically. Kiprop failed to consider that beside the support students receive at home parents have to follow up what they do at school.

In his research on the role of parents in promoting effective learning in Ngong Division Kajiado, Mogute (2010) reveals that most parents have neglected their crucial responsibility of providing time and space for study at home, ensuring homework is done, communicating regularly with the school to monitor students' academic performance. Because of their young age and cognitive development, primary school pupils require more parental guidance and supervision than their counterparts in secondary school does. Thus, creating a need to find out, how parents in Laikipia West Sub-County influence their classes 6, 7 and 8 pupils in academic activities. A survey conducted by Mugo (2011) on the role of parents in promoting effective learning in public secondary schools in Teso South District, Kenya, reveals that although parents are actively involved in roles like paying school levies and attending school meetings, their absence is conspicuously felt in some areas. According to her, parents are accused of not assisting students with homework and following up their academic progress. Mugo employed survey design, targeted 13 secondary schools and used questionnaire, interview guide and observation method of data collection. The researcher feels that when a different method of data collection is used the chance of getting different results is high. A research conducted by Fallow (2000) on students perspective on homework, show that pupils attitude towards homework are often influenced by school environment. The study revealed that there is a relationship between time spent on homework and positive attitude towards school. However, this study, failed to consider a situation where pupils positive attitudes are not reinforced by availability of education support resources and communication between parents, teachers and pupils.

\section{Communication between Parents, Class Teachers and Pupils}

When parents, pupils and teachers engage in academic dialogue, this communication motivates and modifies behaviors of middle school learners towards academic activities (Hein \& Wimer 2007). This implies that in a healthy parent child communication, parents involvement in influencing their children is not affected by their socio-economic status, income, education level, whether they are employed or not ethnicity but on depth in which they discuss academic matters. Most parents according to Hein and Wimer would desire to get as much information about their children's academic performance as possible. However, factors such as inadequate teachers parent communication, hostile school climate and parent's ignorance could hinder them from sharing freely about pupil's academic progress. Ferlazzo (2012) further argued that parents who initiate academic discussions with their children and use more than one mode of communicate for instance verbal and non-verbal, have children who are committed than those whose parents show no interest. Beside the verbal communication, parents are capable of equally influence their children through role modeling. For instance, when illiterate parents enroll in adult education, their sons and daughters view education as a noble activity. They feel spirited, encouraged and empowered to undergo the same process of education just like their parents.

Parent child communication is an important ingredient in the realization of academic achievement. Hoover-Dempsey (2001) in his study on parent instructional interactions with 
Journal of Education and Practice

ISSN 2520-467X (Online)

Vol.5, Issue No.3, pp $35-53,2021$

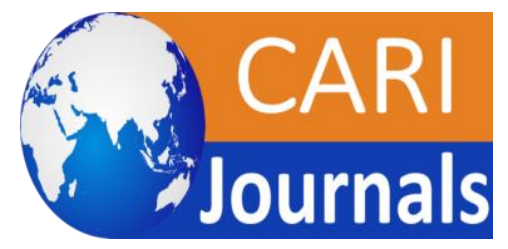

www.carijournals.org

children or collaborative learning conducted at Harvard family research project, highlighted activities such as; breaking down the tasks, explaining academic materials and encouraging pupils to develop personal responsibility as ways to which parents can express concern over their children academic achievements. Parent- child communication could be encouraged at school and home. Strom (2003) in his study on teacher-parent communication reform, pointed that teacher parent communication could not be effective unless the child is brought on board. The purpose for doing so is the realization that the child is the beneficiary whose needs and feelings at school and home could not be ignored. Home interaction includes; verbal interactions where parents spend time with their children discussing academic issues, parents frequently engage their children in dialogue. By joining their children in reading activities, parents support and encourage pupils to develop a culture of reading for fun and relaxation that later boosts their classroom learning.

In a situation where parents are illiterate, other methods of supporting pupils in academic activities could be explored. Stier, Backes and Lamb (2012) in their study on increasing parents-teacher child communication observed that illiterate parents can reinforce pupils' skills by providing them with opportunities to use problem solving negotiation skills, consult teachers or even encourage the older siblings to guide and monitor their brothers and sisters academic progress. Although illiterate parents may use other family members to mentor their children adequate results may not be realized because of other intervening factors such as; inadequate role modeling, and poor time management. The differences in the way parents communicate with teachers and attend school functions could affect pupil's participation in academic activities.

\section{Participating in School Functions}

Parents may not only influence pupils through provision of academic support resources but also seek to find out what happens in the classroom. To achieve this, parents need to participate in school functions; frequently communicate with teachers and school administrators about their children academic progress, consistently attend academic clinics and prize-giving days (Hein and Wimer 2007). Parents' participation in school functions is a catalyst for pupils' academic growth and development. Labahn (2001) observes that the more parents learn about school operations, the more they understand educational processes and the more they make informed decisions about their children education progress. He continues that parents who attend school functions become allies and benefit in understanding their children successes and address difficult situations when they arise. Such parents offer financial support because they understand the pending needs more than their colleagues who never attend such functions.

Besides financial support, parents who frequently visit and attend school functions according to Bonci (2008) can easily monitor pupils' physical, social, emotional and cognitive development. Their visits enable them receive relevant information on how to motivate and assist their pupils from school administrators and class teachers. When parents receive information about their children, they may be motivated to explore more about them and those who are financially stable can enroll in guidance and counseling classes so that they can deeply understand child psychological development. Since attending school functions is one of the ways in which parents may influence pupils' participation in academic activities, not 
Journal of Education and Practice

ISSN 2520-467X (Online)

Vol.5, Issue No.3, pp $35-53,2021$

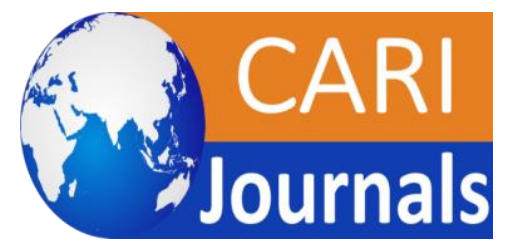

www.carijournals.org

all pupils who might be influenced by such activity, therefore, there need to explore whether parents attendance of school functions have any influence on pupils academic performance.

A study carried out by Thomson (2001) on strengthening family school relationship in Trasmania Australia outlines three benefits of parent's attendance to school functions. Thomson observes that students whose parents attend school functions have improved school behavior and are academically motivated. Such schools have a "healthier" school climate because parents are constantly informed on challenges facing the school and preferable course of action. In his study, Thomson further argued that when parents attend annual general meetings, prize giving days or academic clinics they widen their social network because they interact with parents from other geographical setting. The social interaction enables them to share positive practices that would assist in improving pupils' participation in academic activities. Since parents from the area of study are drawn from different ethnic communities and from diverse social economic activities and cultural backgrounds, their attendance to school meetings and other school functions may perhaps be influenced A study conducted by Whit (2011) on missing school function does not make one a bad parent, reveals that missing school function does not make parents as bad parent as long as they make an attempt to inquire the issues discussed and address them as required. This means that parent needs to understand the importance of school functions in order to respond to demands of class teachers and school administration. When parents fail to attend any school function for one reason or another, they need to make follow up of knowing what issues were discussed and respond effectively. Latif (2002) study on collaborative family -school relationship for children learning pointed that a strong relationship between school and families need from time to time an encounter between parents and teachers. The purpose of such meetings is to maximize pupils output in homework. The study further suggested strategies of helping teachers to develop school- family partnership.

A study conducted by Ferlazzo (2012) on ways to build trust between parents and teachers proposed that parents should be assigned duties at school to enable them be on constant contact with teachers and school administrators, parent need be encouraged to have frequent meeting with teachers during school days in order to enhance their relationship. However, school administrators should be sensitive to time management and the work pressure facing the parent in their daily engagements. He suggested that such meeting could only be successful if they are scheduled at night providing early notice for meetings and activities, providing information for parents who do not attend meeting to keep them informed. In addition, schools should address the issue on parent resource constrains by providing parent with transportation service holding school event near family homes. Some of the suggestions proposed by Latif are not applicable in the context of rural schools in Laikipia West SubCounty because of the distance from school, communication network and even the issue of insecurity. Therefore, alternative measures could be sought to ensure that parents from the area of study are encouraged to attend schools functions. In his study, Latif found that family -school partnership approach is characterized by a belief in shared responsibility for education and socializing children and youth. According to him, this approach advocates collaborative problem solving and shared decision making in order to provide learners with consistent, congruent messages about their homework and behavior. Although families and educators have different roles in enhancing communication, Wayne (2012) observes that in order to encourage school parents collaboration; school administrators should encourage 
Journal of Education and Practice

ISSN 2520-467X (Online)

Vol.5, Issue No.3, pp $35-53,2021$

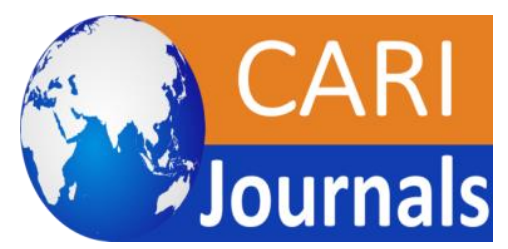

www.carijournals.org

parents to attend school programs. This invitation according to Latif (2002) should aim at building strong relationship and finding ways for working together to promote pupils educational experience. The benefits for family involvement include building pupil's positive attitude towards homework, homework completion, and increased participation in classroom activities, pupil's school attendance and improved test scores.

\section{RESEARCH METHODOLOGY}

A mixed method research design was used where cross sectional descriptive survey was used on quantitative data and phenomenology was used to complement components of qualitative data. Population of 13 public Primary schools was sampled from the total 65 public Primary Schools in the Sub-County. Out of 2,236, pupils' in class 6, 7 and 8, 3 girls and 3 boys were selected per class through stratification and simple random method. Parents/ guardians for the selected pupils were purposively selected regardless of their age, level of education and gender. All class teachers from the sampled schools were targeted and purposively selected. The data was collected using questionnaires, interview guide, document analysis guide and focus discussion guide. Statistical Package for Social Sciences (SPSS) version 17 was used to analyze quantitative data.

\section{RESULTS}

The total numbers of questionnaires presented to class 6,7 and 8 pupils in the sampled public primary schools in Laikipia West Sub-County were 234. Since the researcher used the captive method of data collection, 225 questionnaires were collected. This translates to $96.2 \%$ return rate for pupil's questionnaires. Out of the 39 class teachers expected to attend interview, only 28 attended which is $71.79 \%$. Among the 234 parents sampled only 150 turned up for focus group discussion that translates to $64.10 \%$. Out of the 13 schools sampled, only nine returned the document analysis guide that translates to $69.2 \%$.

\section{Parents Involvement in Teaching and Learning Process.}

Parent's involvement in the teaching and learning process encourages pupils to participate in academic activities as cited by Desforges (2003). Although parental involvement may take many forms such as good parenting in the home, provision of a secure and stable environment, this study was concerned with whether parents assist pupils with homework, attend school functions, communicate with teachers and pay school levies.

\section{Assisting Pupils With Homework}

Parents and teachers are key players in influencing pupils in academic activities. The assignments given at school ought to be reinforced by parents at home by assisting children with homework. Table 1 shows pupils response on whether parents assist them with homework.

Table 1: Parents/guardian assisting with homework

\begin{tabular}{lcc}
\hline Response & Frequency & Percent \\
\hline Yes & 162 & 72.0 \\
No & 62 & 27.6 \\
No. Response & 1 & 0.4 \\
Total & $\mathbf{2 2 5}$ & $\mathbf{1 0 0 . 0}$ \\
\hline
\end{tabular}


Journal of Education and Practice

ISSN 2520-467X (Online)

Vol.5, Issue No.3, pp $35-53,2021$

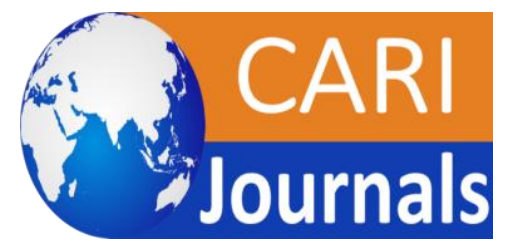

www.carijournals.org

The research required the pupils to answer whether parents assisted them with homework. Table 1 indicates that $72.0 \%$ of the pupil respondents get assistance from parents/guardians in doing their homework while $27.6 \%$ do not. Therefore, majority of parents/ guardians in the sampled schools assist pupils with homework. This trend could be initiated by the fact that majority of the parents/guardians value education. assisting pupils with homework can involve parents in the schooling process of their children. It can enhance parents' appreciation of education. It gives parents an opportunity to express positive attitudes about the value of success in school.

When asked whether parents check on their assignment, pupil's responses were as presented in Table2.

Table 2: Pupils Response on Parents Checking Assignment

\begin{tabular}{lll}
\hline Responses & Frequency & Percent \\
\hline Disagree & 43 & 19.1 \\
Agree & 182 & 80.9 \\
Total & $\mathbf{2 2 5}$ & $\mathbf{1 0 0 . 0}$ \\
\hline
\end{tabular}

When asked whether parents check on their homework after school, the pupil's respondents gave the following results, $80.9 \%$ of the pupil's respondents agree that their parents check on their assignments after school, while $19.1 \%$ disagree. This is in line with the work of Joan et al. (2004) who argued that students benefit when parents and other adults offer specific positive responses to student homework performance.

The issue of checking on pupil's assignment could further be attributed to the fact that most of the parents in Laikipia West Sub County have attained primary education, and therefore it is easy for them to follow up on their children's assignments at home. This is supported by one of the parents reported that after checking on the daughter's homework, she discovered that it is not marked. She went to school to consult with the teacher concerned. However, the $19.1 \%$ of the pupil's respondents who said that parents do not check on their assignment attributed it to parents being busy in workplace, parent's illiteracy and lack of interest in academic issues. When asked whether they check on pupil's homework, some admitted that illiteracy is a challenge but one parent humorously said,

"I ask my older siblings to check on their brothers and sisters homework and report to me and in fact it has worked. Sometimes I check on my children exercise books not that I know but just to convince her that I am concerned with what she does in school".

This statement alludes that parents could still support their children with homework even when they are illiterate, by asking other siblings and even asking class teachers. This is in line with Menahem et al (2003) view that when parents assist pupils with homework, pupils develop positive habits and attitudes towards learning. The social learning theory earlier established by Bandura (1977) advocates that cognitive thought process of pupils are influenced by the culture of the people they live with. This means that when parents establish a culture of supporting and assisting pupils with homework, pupils are positively influenced to appreciate and take homework seriously. 
Journal of Education and Practice

ISSN 2520-467X (Online)

Vol.5, Issue No.3, pp $35-53,2021$

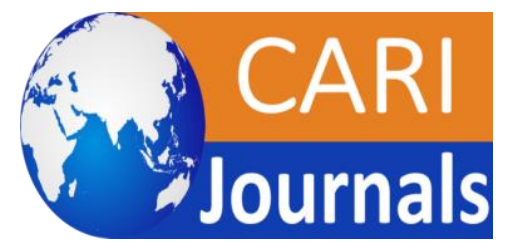

www.carijournals.org

When asked whether parents assist with homework, most of the class teachers said that some of the parents are reluctant to assist their children with homework. Similar sentiments were expressed in USDE (2003) report that parent's involvement in pupil's assignment can create either a positive or a negative effect on the value of homework.

\section{Parents Attending School Functions}

According to this study, school functions include academic clinics, parent's teachers meetings (PTA), prize-giving days, school exhibition days and other functions that bring parents together. In determining whether parents attend school functions, pupils participants gave responses as illustrated in Table 3.

Table 3: Pupils Response on parents attending school functions

\begin{tabular}{llc}
\hline Response & Frequency & Percent \\
\hline Yes & 205 & $\mathbf{9 1 . 1}$ \\
No & 20 & $\mathbf{8 . 9}$ \\
Total & $\mathbf{2 2 5}$ & $\mathbf{1 0 0 . 0}$ \\
\hline
\end{tabular}

Table 3 illustrates that $91.1 \%$ of the pupils who participated in the study from the sampled public primary schools of Laikipia West Sub County agreed that parents attend schools functions and only $8.9 \%$ disagreed. This means that most parents in Laikipia West Sub County attend school functions, which is in agreement with Desforges (2003), that parents should play a role not only the in promotion of their own children's achievements but more broadly in school improvement and the democratization of school governance.

\section{Communication with class Teachers and Pupils}

The level of communication between parents, teachers and pupils determines the degree to which they engage each other in the teaching and learning process. Table 4 gives the summary of pupil's response as to whether parents communicate with class teachers and pupils.

Table 4 Parents Communication with Class Teachers and Pupils

\begin{tabular}{lll}
\hline Response & Frequency & Percent \\
\hline Agree & 115 & $\mathbf{6 8 . 9}$ \\
Disagree & 70 & $\mathbf{3 1 . 1}$ \\
Total & $\mathbf{2 2 5}$ & $\mathbf{1 0 0 . 0}$ \\
\hline
\end{tabular}

As to whether parents/guardians in Laikipia West Sub-County visit schools to consult teachers on their children academic performance, the results in Table 4 reveal that $68.9 \%$ of the pupil's respondents agree while $31.11 \%$ disagree. Therefore, majority of the parents/guardians have interest in their children's academic achievements and only a few are not. The fact that parents hold academic discussions with teachers and pupils encourages them to consider teachers not as strangers but partners in the education process of their children. This is in line with Epstein and Van, (2001) view that parents need to be encouraged to contact the teachers frequently not only during the time of crisis but also when they are available. Laurie (2003) further supports that if a child is having difficulty with homework, parents 
Journal of Education and Practice

ISSN 2520-467X (Online)

Vol.5, Issue No.3, pp $35-53,2021$

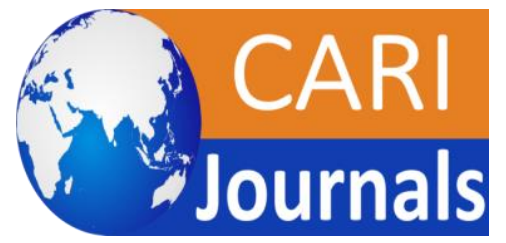

www.carijournals.org

When asked whether parents visit school to consult on pupil's academic performance, the teachers interviewed pointed that some parents would only visit school when the child is sent home and sometimes-on issues of indiscipline. Responses from the teachers interviewed reveal that some parents consider school as an alien place owned by head teachers, teachers and pupils. Their business is only to pay money. This contradicts Hein \& Wimer (2007) view that, communication motives and modifies behavior of the learners. Therefore, parents need to hold frequent discussions with teachers and pupils in order to understand their roles in child education. The interest shown by parents of Laikipia West sub County towards education of their children could be attributed to the parent's change of attitude toward education and the perception that education can lead to better status in the society. One of the parents affirmed, "I take my children to school, so that she can get a white color job" This means that some parents in the area of study understand the role of education as a conveyer belt towards a bright future. The teachers reported that the few who do not follow up with their children are cannot afford the rigorous demands of education since some of them are old while others are illiterate. This notwithstanding, some of them are not interested on issues concerning education and are never committed to school visits.

\section{Hypothesis Testing}

To determine the relationship between independent and dependent variables a correlation coefficient analysis was used. Variables representing parental influence includes; attending school functions, communication with class teachers and pupils, and assisting with homework and payment of school levies. After computing using correlation coefficient analysis, the researcher generated the following results:

\section{Table 5: Correlations}

\begin{tabular}{|c|c|c|c|c|c|c|c|c|c|c|}
\hline \multicolumn{2}{|c|}{ Variables } & \multirow{2}{*}{$\begin{array}{r}\text { Mean } \\
.498\end{array}$} & \multirow{2}{*}{$\begin{array}{c}\begin{array}{c}\text { Std } \\
\text { Dev }\end{array} \\
.501\end{array}$} & \multirow{2}{*}{$\begin{array}{c}\begin{array}{c}\text { No. } \\
\text { respondents }\end{array} \\
221\end{array}$} & \multirow{2}{*}{ 1. } & \multirow[t]{2}{*}{2.} & \multirow[t]{2}{*}{3.} & \multirow[t]{2}{*}{4.} & \multirow[t]{2}{*}{5.} & \multirow[t]{2}{*}{6.} \\
\hline 1. & Gender & & & & & & & & & \\
\hline \multirow[t]{2}{*}{2.} & Age & 3.57 & .688 & 221 & $.171^{*}$ & 1 & & & & \\
\hline & & & & & .011 & & & & & \\
\hline \multirow[t]{2}{*}{3.} & Class & 2.010 & .811 & 223 & -.006 & $.433^{* *}$ & 1 & & & \\
\hline & & & & & .934 & .000 & & & & \\
\hline \multirow[t]{2}{*}{4.} & Parents assisting & 3.255 & .967 & 224 & $-.146^{*}$ & $-.168^{*}$ & -.016 & 1 & & \\
\hline & & & & & .031 & .013 & .810 & & & \\
\hline \multirow{2}{*}{\multicolumn{2}{|c|}{$\begin{array}{l}\text { 5. Parents } \\
\text { Attending } \\
\text { function }\end{array}$}} & 1.707 & .512 & 225 & .050 & -.115 & -.004 & $.261^{* *}$ & $.192^{* *}$ & \\
\hline & & & & & .457 & .088 & .948 & .000 & .004 & \\
\hline \multirow{2}{*}{\multicolumn{2}{|c|}{$\begin{array}{l}\text { 6. Parents } \\
\text { communicating with } \\
\text { class teachers and pupils }\end{array}$}} & 2.498 & .690 & 223 & -.069 & -.116 & .029 & $.424^{* *}$ & .050 & 1 \\
\hline & & & & & .306 & .087 & .673 & .000 & .458 & \\
\hline
\end{tabular}

\section{Hypothesis One}

Taking the level of significance as 0.05 and p-value 0.146 the researcher failed to reject the null hypothesis based on the data collected and therefore concludes that Gender is negatively 
Journal of Education and Practice

ISSN 2520-467X (Online)

Vol.5, Issue No.3, pp $35-53,2021$

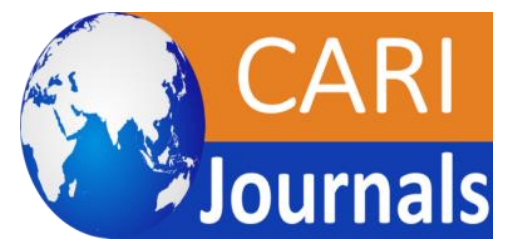

www.carijournals.org

correlated with parent assisting in homework. This means that there is no significant relationship between pupil's gender and parents assisting with homework. Therefore, pupils' gender has no effect on parents assisting and failing to assist pupils with homework. The observation agrees with Bonci and Cole (2011) view that parents have the ability to influence pupil's participation in academic activities. Parents could employ various interventions such as, checking on pupil's assignments, meeting regularly with teachers and administering disciplinary measures for bad results.

\section{Hypothesis Two}

Taking the level of significance as 0.01 and p-value 0.26 , the researcher rejected the null hypothesis and therefore concludes parents' assisting pupil with homework is positively and strongly correlated with parents attending school function. This shows that when parents attend school functions, they become more committed in assisting pupils with homework. Meaning those parents who attend school functions understand the kind of assistance their children require and therefore execute it effectively. The class teachers interviewed pointed that most parents follow up their children academic progress as well as support them by buying learning resources. Such parents also visit school to find out how their children are performing and in a situation where children are sent home due to school levies, they respond immediately by either paying or negotiating for more time with school administrators.

\section{Hypothesis Three}

Taking the level of significance as 0.00 and p-value 0.424 , the researcher failed to reject the null hypothesis and concludes that there is a strong correlation between parents attending school functions and parents communication with class teachers and pupils. It is further positively and strongly correlated with pupils asking questions in class $\left(\mathrm{r}=0.162^{*}, \mathrm{p}<0.05\right)$. This implies that when parent attend school function they also find time to inquire about their children academic performance from class teachers. Through such interactions, their relationship with the teachers is strengthened such that they freely report to teachers whenever a pupil is absent from school. In addition, it encourages parents to follow up on pupil's performance.

\section{Conclusion}

Based on the findings of the study, the following conclusions were made: First most of the parents are mainly motivated by social, economic, educational and moral reasons to educate their children. Therefore, the researcher concludes that most of the parents in the area of study are concerned with the integral formation of their children, which helps them to relate well with others and open them to the job market. Secondly, most parents are involved in the teaching and learning process as well as provision of academic support resources for their children despite the challenges such as illiteracy, poverty, old age and cultural values and practices. Therefore, the wish of most parents in the area of study is to ensure that their children receive quality education.

Thirdly, most of the pupils respond to parents influence by asking questions in class, attending study groups, finishing homework in time and attending school regularly. The researcher therefore concludes that most of the pupils from the sampled school are motivated to undertake academic activities. Fourthly, there are numerous challenges facing the parents, these challenges range from insecurity, poverty, ignorance, cultural beliefs and practices and 
Journal of Education and Practice

ISSN 2520-467X (Online)

Vol.5, Issue No.3, pp $35-53,2021$

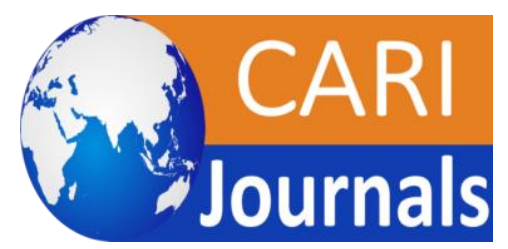

www.carijournals.org

negative attitude towards school. Therefore, the researcher concludes that most parents from the area of study are willing to support their children, if some of these challenges are alleviated.

\section{Recommendations}

Based on the conclusions drawn from the findings, the researcher made the following recommendations; the church leaders, education officers and political leaders should take the initiative of creating awareness in the community concerning the importance of child education. This should aim at widening parent's scope and interest in educating their children. Some of the errant parents should be encouraged and sensitized on their roles such as monitoring pupil's academic performance by attending school functions and frequent communication with class teachers and school administrators. Chiefs, village elders and education officers can carry out this program during "barazas" and educational forums. The County as well as National Governments should take the initiative of promoting parents economically by sponsoring education fully, assisting the neediest families and ensuring that every child goes to school. School administrators and the church leaders should be given the responsibility of identifying the needy pupils

The teachers and parents should communicate frequently in order to address the challenges facing the pupils in school and at home some of which could lead to pupils dropping out of school. Class teachers should inform delinquent pupils on the importance of participating ingroup work, attending school, and asking questions in class. The teachers should also encourage pupils to finish homework in time by marking the assignments and encouraging the weak pupils. To address the issue of insecurity the researcher calls upon all the concerned parties spearheaded by the National and County Governments to establish peace caravans, engaging the warring communities into frequent dialogue through their elders and Church leaders, establishing police posts at black spots of cattle rustling in the Sub-County and disarming the communities who are still in possession of firearms.

The church leaders and community elders should advocate peaceful co-existence among the various ethnic communities living in Laikipia West Sub-County. This could be achieved by establishing common social amenities like hospitals, schools as well as shopping centre in areas that are prone to conflict. This will encourage and promote dialogue among these communities. The County Government should organize inter-cultural festivals and games to draw together people from different ethnic communities in order promote an understanding, respect and appreciation of others and their property. County Government in conjunction with the Ministry of tourism and wild life should erect electric fence along the game reserves or deploy more game wardens to the area. The National Government in consultation with the wild life officials should also explore the possibility of relocating wild animals to the neighboring game reserves or national parks.

\section{REFERENCES}

Bandura, A. (1986). Social foundation of thought action: a social cognitive theory. New Jersey: Prentice Hall Englewood Cliffs

Bonci. A. (2008). A Research review: the importance of families and the home environment. national literacy trust. Il Saint Xavier University and Pearson Achievement Solutions, Inc.

Case, A. (2008). Why your students do not do homework, New York: Brooklyn. 
Journal of Education and Practice

ISSN 2520-467X (Online)

Vol.5, Issue No.3, pp $35-53,2021$

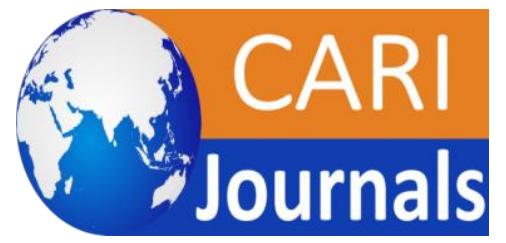

$\underline{\text { www.carijournals.org }}$

Cohen, L. Manion, L. \& Marrison, K. (2005). Research methods in education. London: Sage Publications.

De Jong, W. \& Creemers. (2000). Research on the effects of homework: www center for public education.org.

Desforges, C \& Abouchaar A. (2003). The impact of parental involvement, parental support and family education on pupil achievements and adjustment. A literature review. DFES Research Report 433.

Epstein, J. L. \& Van Voorhis, F. L. (2001). Teachers' role in designing homework, Educational Psychology, 36(3), pp 181-193.

Farrow. Tymms \& Henderson. (2000). Homework and its contribution to learning: University of Leeds

Hein, D. L. \& Wimer, S. L. (2007). Improving homework completion and motivation of middle school students through behavior modification, graphing, and parent communication. Chicago, Il saint Xavier university and person achievement Solutions, Inc.

Hoover-Dempsey, K. V., Battiato, A. C., Walker, J. M. T., Reed, R. P., Dejong, M., \& K. P. (2001). Parent involvement in homework. educational psychologist, No 36, pp 195210.

Kiprop, F. J. (2005). An Investigation into influence of parental background on students' attitude towards education in secondary schools. A case study of mbogo-ini division, Nakuru district. Unpublished Master's Thesis. The Catholic University of Eastern Africa, Kenya.

Kiveu, M. N. \& Maiyo, N. (2009). The impact of cost sharing on internal efficiency of public secondary school in ndivisi division, bungoma district kenya. Unpublished research paper

Labahn, S. (1995). Education and parental involvement in secondary schools: problems, solutions and effects. Educational psychology interactive retrieved from http://www.Edpsyc interactive/files/pavinvol.html.

Latif, A. (2002). Family involvement in children education: Massachusetts institute of technology 30 wads worth St. E53-320

Laurie M.R., McGrath J., Menahem H., (2003). Homework tips for parents ED Pubs Education Publications Center U.S. Department of Education

Learning resources centre study skills handout (2013). Importance of study groups. www.bmcc.cuny.edu/lvc/studyskills/T...

Menahem, H. McGrath, J. \& Rich, M. L. (2003). Helping with homework. Washington. Education Publication Center.

Mogute Z. M. (2010). Role of parents in promoting effective learning in public secondary schools in ngong division kajiado north district. Unpublished Master's Thesis. The Catholic University of Eastern Africa, Kenya.

Mugo, W. R. (2011). The role of the parents in promoting effective learning in public secondary schools in teso south district, busia county. Unpublished Master's Thesis. The Catholic University of Eastern Africa, Kenya.

Stephen W. Littlejohn \& Karen A. Foss, (2009), Encyclopedia of communication theory social interaction theories 
Journal of Education and Practice

ISSN 2520-467X (Online)

Vol.5, Issue No.3, pp $35-53,2021$

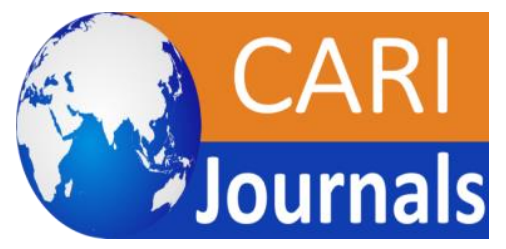

Thomson, P. (2001). Strengthening family school relationships: a story about using research to develop policy and practices in tasmania australia. (Web) http//www.4 calgary.ca/ ill/volume 6/Thomson.htms, retrieved: 2012/4/12

Tshabalala, M. M. (2008). An empowerment approach to parental involvement in the primary school. south africa: North West University press.

Wayne, G. \& Santead (2012). Annual parenting meeting school wide setting: Bismarck North Dakota 